Waste Isolation Safety Assessment Program

\title{
Controlled Sample Program Publication Number 2: Interlaboratory Comparison of Batch Kd Values
}

\author{
J. F. Relyea \\ R. J. Serne
}

June 1979

Prepared for the

Office of Nuclear Waste Isolation

U.S. Department of Energy

under Contract EY-76-C-06-1830

Pacific Northwest Laboratory Operated for the U.S. Department of Energy by Battelle Memorial Institute 
NOTICE

This report was prepared as an account of work sponsored by the United States Government. Neither the United States nor the Department of Energy, nor any of their employees, nor any of their contractors, subcontractors, or their employees, makes any warranty, express or implied, or assumes any legal liability or responsibility for the accuracy, completeness or usefulness of any information, apparatus, product or process disclosed, or represents that its use would not infringe privately owned rights.

The views, opinions and conclusions contained in this report are those of the contractor and do not necessarily represent those of the United States Government or the United States Department of Energy.

\author{
PACIFIC NORTHWEST LABORATORY \\ operated by \\ BATTELLE \\ for the \\ UNITED STATES DEPARTMENT OF ENERGY \\ Under Contract EY-76-C-06-1830
}

\begin{tabular}{|c|c|c|}
\hline \multicolumn{3}{|c|}{$\begin{array}{c}\text { Printed in the United States of Am } \\
\text { Available from } \\
\text { National Technical Information Se } \\
\text { United States Department of Comn } \\
5285 \text { Port Royal Road } \\
\text { Springfield, Virginia } 22151\end{array}$} \\
\hline ice: & Printed Copy & S__ : Microfic \\
\hline & "Pages & $\begin{array}{c}\text { NTIS } \\
\text { Selling Price }\end{array}$ \\
\hline & $001-025$ & 54.00 \\
\hline & $026-050$ & $\$ 4.50$ \\
\hline & $051-075$ & $\$ 5.25$ \\
\hline & $076-100$ & $\$ 6.00$ \\
\hline & $101-125$ & $\$ 6.50$ \\
\hline & 126.150 & $\$ 7.25$ \\
\hline & $151-175$ & $\$ 8.00$ \\
\hline & $176-200$ & $\$ 9.00$ \\
\hline & $201-225$ & $\$ 9.25$ \\
\hline & $226-250$ & $\$ 9.50$ \\
\hline & $251-275$ & $\$ 10.75$ \\
\hline & $276-300$ & $\$ 11.00$ \\
\hline
\end{tabular}


PNL-2872

UC-70

\section{9}

Waste Isolation Safety Assessment Program

CONTROLLED SAMPLE PROGRAM

PUBLICATION NUMBER 2:

INTERLABORATORY COMPARISON OF BATCH KD VALUES

J. F. Relyea

R. J. Serne

June 1979

Prepared for the

Office of Nuclear Waste Isolation

U.S. Department of Energy

under Contract EY-76-C-06-1830

Pacific Northwest Laboratory

Richland, Washington 99352 


\section{ACKNOWLEDGMENT}

This research was supported by the Waste Isolation Safety Assessment Program being conducted by Pacific Northwest Laboratory. This program is sponsored by the Office of Nuclear Waste Isolation, which is managed by Battelle Memorial Institute under its contract with the Department of Energy. 



\section{SUMMARY}

The objectives of the controlled sample program interlaboratory comparison were to: 1) ascertain whether different experimenters obtain the same results for the adsorption of $\mathrm{Cs}, \mathrm{Sr}$ and $\mathrm{Pu}$ using common rocks, standard solutions and a prescribed method; and 2) compare the results obtained by individual laboratories using different experimental methodologies and resolve any differences found or determine what conversions can be made to compare results from one method with another.

Results from Objective 1 indicate that several parameters that were uncontrolled may have affected results. The uncontrolled parameters were: 1) method of tracer addition to solution, 2) solution to rock ratio, 3 ) initial tracer concentration in influent solution, 4) particle size distribution, 5) solid-solution separation method, 6) sample containers, and 7) temperature.

Observed Kds for $\mathrm{Cs}$ and $\mathrm{Sr}$ in brine showed agreement among laboratories for both 1 imestone and basalt rock samples. Comparable results were also found for $\mathrm{Sr}$ and $\mathrm{Cs}$ in the basalt groundwater. Results for $\mathrm{Kd}(\mathrm{Cs})$ in the 1 imestone groundwater varied over three orders of magnitude, and $\mathrm{Kd}(\mathrm{Sr})$ varied by one order of magnitude in the limestone system. Observed $\mathrm{Kd}$ values for $\mathrm{Pu}$ typically varied by two to three orders of magnitude in all systems studied.

Adsorption of $\mathrm{Pu}$ by container walls and by colloidal particles caused much of the variation in $\mathrm{Kd}(\mathrm{Pu})$. Direct measurement of $\mathrm{Pu}$ adsorbed by the rock (rather than measured by the difference between influent and effluent activities) also failed to reduce the $\mathrm{Kd}(\mathrm{Pu})$ variability. 



\section{CONTENTS}

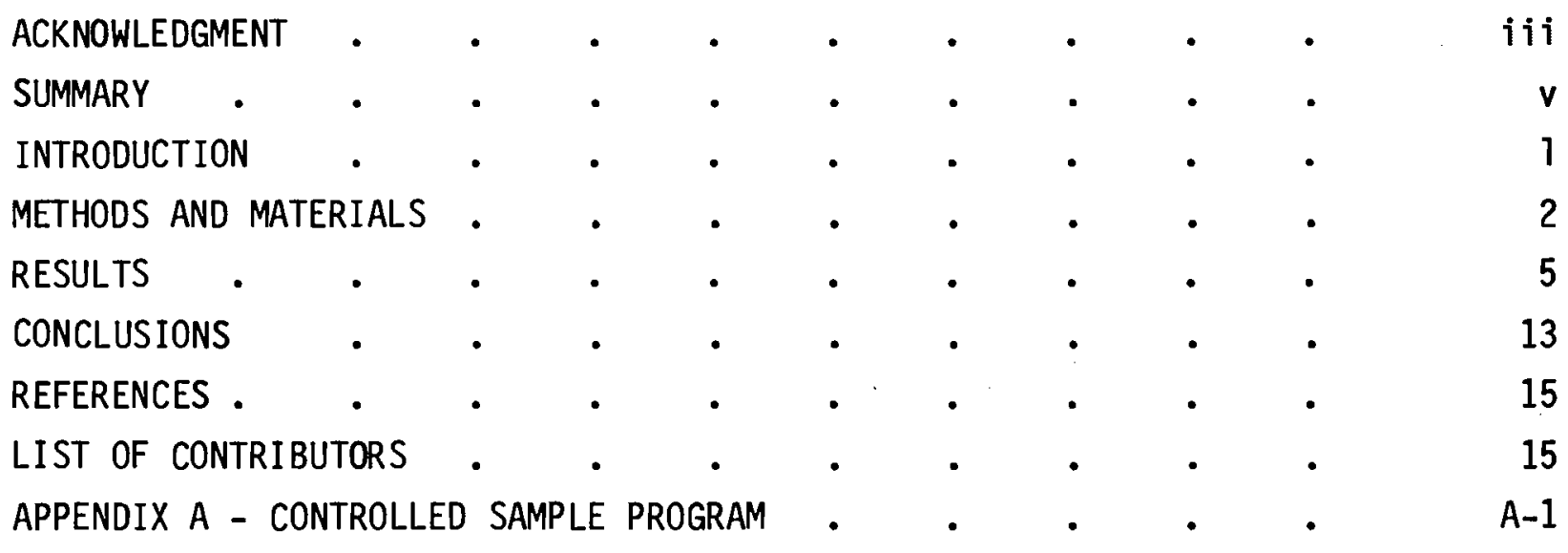


. 


\section{INTRODUCTION}

Disposal of radioactive waste in deep geologic media has been proposed as a method that would isolate waste from the biosphere for long periods of time. This method is intended to allow radioactive decay to reduce the waste's radiotoxicity and to preclude contact between the biosphere and radioactive waste in amounts which could adversely affect humans or their environment. To analyze the effectiveness of deep geologic disposal, defensible safety asessments of geologic repository systems must be made that cover extended periods of geologic time. The Waste Isolation Safety Assessment Program (WISAP) has been established to develop capability for making these analyses. These analyses require data on the sorption-desorption behavior of radionuclides in geologic media. Reproducible, defensible data based on scientifically accepted methodologies must be obtained for input to the safety assessment models.

Presently, investigators determine sorption-desorption Kds, retardation factors, or radionuclide migration rates using a variety of experimental methods. Data currently being obtained are dependent on the methodology used, and the type of solution and geologic media studied. A controlled sample program was established under WISAP to resolve the differences found among methodologies and to determine which method or methods are most appropriate for providing accurate data on the migration of radionuclides in geologic media.

The objectives of the controlled sample program interlaboratory comparison were to: 1) ascertain whether different experimenters obtain the same results for the adsorption of $\mathrm{Cs}, \mathrm{Sr}$ and Pu using common rocks, standard solutions and a prescribed method; and 2) compare the results obtained by individual laboratories using different experimental methodologies and resolve any differences found or determine what conversions can be made to compare results from one method with another. 


\section{METHODS AND MATERIALS}

Large quantities of rocks were provided to all WISAP subcontractors involved in sorption-desorption data development and to the Atomic Energy of Canada Ltd. (AECL). The rock samples were analyzed at Pacific Northwest Laboratory $(P N L){ }^{(a)}$ to characterize the mineralogy, the cation exchange capacity (CEC) and surface area. Mineralogy was determined by X-ray diffraction and microprobe analysis in conjunction with bulk chemical analysis. The characterizations of the two rock types used in this program, oolitic limestone and sentinal gap basalt, are given in Table 1.

\section{TABLE 1. Characterization of Rocks Used in Controlled Sample Program}

\begin{tabular}{|c|c|c|}
\hline & $\begin{array}{c}\text { 0o litic } \\
\text { Limestone }\end{array}$ & $\begin{array}{c}\text { Sentinal Gap } \\
\text { Basalt }\end{array}$ \\
\hline $\begin{array}{l}\text { Cation Exchange Capacity } \\
\quad(\text { meq } / 100 \mathrm{~g} \pm \text { s.d.) }\end{array}$ & $42 \pm 16$ & $4.7+0.2$ \\
\hline $\begin{array}{l}\text { Surface Area }\left(\mathrm{m}^{2} / \mathrm{g}\right) \\
\text { BET } \\
\text { Ethylene Glycol }\end{array}$ & $\begin{array}{c}0.75 \\
5.6 \pm 1.7\end{array}$ & $10.3^{2.5} \pm 1.0$ \\
\hline Minera logy & $\begin{array}{l}\text { Calcite } 99 \% \\
\text { Clays } 1 \%\end{array}$ & $\begin{array}{l}\text { Plagioc lase } \\
\qquad \mathrm{Ab}_{55}-\mathrm{Ab}_{40} 44 \% \\
\text { Pyroxenes } 32 \% \\
\text { Groundmass } 13 \% \\
\text { Metal1ic 0xides } 6 \% \\
\text { Clays } 5 \%\end{array}$ \\
\hline
\end{tabular}

Recipes for solutions and instructions used in 0bjective 1 were prescribed for all participants (see Appendix A). A representative limestone solution and a representative basalt solution were used with the respective

(a) Operated by Battelle Memorial Institute 
rocks. A brine recipe (WIPP Brine \#B, slightly altered) was also used with both rock types. These synthetic groundwater compositions are given in Table 2. Four experiments were carried out by each participant:

$\# 1$ - limestone with the limestone groundwater

\#2 - limestone with the brine solution

\#3 - basalt with the basalt groundwater

\#4 - basalt with the brine solution.

The $\mathrm{Kds}$ for $\mathrm{Pu}, \mathrm{Sr}$ and $\mathrm{Cs}$ were to be determined in each of the four experiments by each of the laboratories.

TABLE 2. Controlled Sample Program Synthetic Groundwater Compositions

\begin{tabular}{|c|c|c|c|c|c|c|}
\hline \multirow[b]{2}{*}{ Groundwater Type } & \multirow[b]{2}{*}{ Cation } & \multicolumn{2}{|c|}{ Concentration } & \multirow[t]{2}{*}{ Anion } & \multicolumn{2}{|c|}{ Concentration } \\
\hline & & $(\mathrm{mg} / \mathrm{T})$ & $(\mathrm{meq} / \mathrm{T})$ & & $(\mathrm{mg} / 1)$ & (meq/7) \\
\hline Limestone water & $\mathrm{Ca}^{2+}$ & 50 & 2.50 & $\mathrm{HCO}_{3}^{-}$ & 153 & 2.51 \\
\hline \multirow[t]{3}{*}{$\mathrm{pH} 8.0$ to 8.4} & $\mathrm{Mg}^{2+}$ & 3.6 & 0.30 & $\mathrm{SO}_{4}^{2-}$ & 14.4 & 0.30 \\
\hline & $\mathrm{Na}^{+}$ & 2.3 & 0.10 & $\mathrm{Cl}^{-}$ & 3.5 & 0.10 \\
\hline & $\mathrm{K}^{+}$ & 0.4 & 0.01 & & & \\
\hline Basalt water & $\mathrm{Ca}^{2+}$ & 6.5 & 0.33 & $\mathrm{HCO}_{3}$ & 58 & 0.95 \\
\hline \multirow[t]{3}{*}{$\mathrm{pH} 7.7$ to 8.2} & $\mathrm{Mg}^{2+}$ & 1.0 & 0.08 & $\mathrm{SO}_{4}^{2-}$ & 23 & 0.48 \\
\hline & $\mathrm{Na}^{+}$ & 30.0 & 1.30 & $\mathrm{Cl}^{-}$ & 16 & 0.46 \\
\hline & $\mathrm{K}^{+}$ & 9.0 & 0.23 & $\mathrm{~F}^{-}$ & 0.7 & 0.04 \\
\hline WIPP Brine \#B & $\mathrm{Ca}^{2+}$ & 900 & 45.00 & $\mathrm{HCO}_{3}^{-}$ & 10 & 0.16 \\
\hline slightly altered & $\mathrm{Mg}^{2+}$ & 10 & 0.82 & $\mathrm{SO}_{4}^{2-}$ & 4190 & 87.3 \\
\hline \multirow[t]{4}{*}{$\mathrm{pH} 6.0$ to 7.0} & $\mathrm{Sr}^{2+}$ & 1.5 & 0.03 & $\mathrm{Cl}^{-}$ & 175,000 & 4936 \\
\hline & $\mathrm{Na}^{+}$ & 115,000 & 5000 & $\mathrm{BO}_{3}^{3-}$ & 10 & 0.51 \\
\hline & $\mathrm{K}^{+}$ & 15 & 0.38 & $\mathrm{Br}^{-}$ & 400 & 5.00 \\
\hline & $\mathrm{Cs}^{+}$ & 1.0 & 0.01 & & & \\
\hline
\end{tabular}


Before contact with the prepared rock, spiked groundwater (groundwater containing radionuclides) was equilibrated for at least three days with $\mathrm{pH}$ adjustment as needed and filtered through a $0.45 \mu \mathrm{m}$ filter (or smaller). $B l$ ank containers (spiked groundwater without rocks) were required to correct nuclide activity caused by container wall adsorption of the tracers. The rocks were equilibrated with a cold (nonradioactive) wash of the appropriate groundwater solution for 48 hours and then separated by centrifugation. The cold wash was repeated and the spiked groundwater was contacted with the rock. After contact for seven days, the rocks and solutions were separated for determination of the tracer distribution between the solid and solution phases. The Kds were calculated using the following formula:

$$
K d=\frac{r A i-A e}{A e} \frac{V}{W}
$$

where

$$
\begin{aligned}
r= & \text { ratio of tracer solution to total solution } \\
A i= & \text { radionuclide activity in solution from the blank container (spiked } \\
& \text { influent groundwater without rocks) } \\
A e= & \text { radionuclide activity left in solution after contact with the geo- } \\
& \text { media for seven days (effluent) } \\
V= & \text { total solution volume } \\
W= & \text { mass of the geomedia used. }
\end{aligned}
$$

The Kd has dimensions of $\mathrm{ml} / \mathrm{g}$. 


\section{RESULTS}

Results of Objective 1 (interlaboratory comparison) have been received from nine laboratories: Argonne National Laboratory (ANL), Atomic Energy of Canada Ltd. (AECL), Los Alamos Scientific Laboratory (LASL), Lawrence Berkeley Laboratory (LBL), Lawrence Livermore Laboratory (LLL), Oak Ridge National Laboratory (two groups, ORNL-I and ORNL-II), Pacific Northwest Laboratory (PNL), and Rockwe 11 Hanford Operations (RHO).

After receiving the data, we discovered that several parameters had varied among laboratories, including: 1) the method for adding tracer radionuclides to groundwater solutions, 2) the solution to rock ratio, 3) the final tracer concentration in the influent solutions, 4) the final distribution of particle sizes used, 5) the solid-solution separation method, 6) sample containers used, and 7) temperature. Initially, parameters were thought to have had little influence on Kd values.

The addition of tracer to the groundwater solutions was accomplished by either evaporating an aliquot of radionuclide and adding synthetic groundwater solution or by adding the spike (from an acid stock solution) to the synthetic groundwater and adjusting the $\mathrm{pH}$ back to the initial value. The necessity for $\mathrm{pH}$ adjustment is essentially eliminated by adding the tracer in the evaporated form; this may prevent inadvertent precipitation of the tracer resulting from overcorrection of the $\mathrm{pH}$ to high values. On the other hand, effects on valence states, especially of $\mathrm{Pu}$, caused by evaporation to dryness may complicate the interpretation of the data.

Possibly the solution to solid ratio affects the composition of the solution that results from weathering of the solid or the solid surface. The reported solution to solid ratios were 15:1 in all cases except the ratio of 20:1 for ${ }^{137} \mathrm{Cs}$ and ${ }^{85} \mathrm{Sr}$ adsorption experiments conducted at PNL.

The tracer concentrations that were reported by the different laboratories are shown in Table 3. Molar concentrations varied over several orders of magnitude for each nuclide used. The variations in observed $\mathrm{Kds}$, however, do not correlate with influent radionuclide concentrations. 
TABLE 3. Tracer Concentrations (Molar)

\begin{tabular}{|c|c|c|c|}
\hline & Cs* & $S r^{*}$ & $\mathrm{Pu}^{*}$ \\
\hline ANL $(a)$ & $<6 \times 10^{-12}$ & $\leq 3 \times 10^{-13}$ & $\leq 3 \times 10^{-12}$ \\
\hline$A E C L^{(b)}$ & $\overline{<2} \times 10^{-7}$ & $<5 \times 10^{-6}$ & $<1 \times 10^{-6}$ \\
\hline LASL & $\leq 2 \times 10^{-7}$ & $\leq 2 \times 10^{-12}$ & $<2 \times 10^{-13}$ \\
\hline LBL & $<5 \times 10^{-9}$ & $<5 \times 10^{-8}$ & $<2 \times 10^{-12}$ \\
\hline LLL & $<1 \times 10^{-7}$ & $\leq 1 \times 10^{-9}$ & $\leq 1 \times 10^{-11}$ \\
\hline ORNL-I & $\leq 1 \times 10^{-6}$ & $\leq 1 \times 10^{-6}$ & $\leq 1 \times 10^{-6}$ \\
\hline PNL & $<3 \times 10^{-9}$ & $<3 \times 10^{-13}$ & $<3 \times 10^{-13}$ \\
\hline
\end{tabular}

* $137 \mathrm{Cs},{ }^{85} \mathrm{Sr}$ and $237 \mathrm{Pu}$ used unless stated otherwise (a) ${ }^{134} \mathrm{Cs}$ used instead of $137 \mathrm{Cs}$

(b) $90 \mathrm{Sr}$ and $239 \mathrm{Pu}$ used instead of ${ }^{85} \mathrm{Sr}$ and $237 \mathrm{Pu}$

The approximate particle size range of the rocks was determined at PNL by crushing and dry sieving before distribution to the participants. Fine particles, especially rock dust below the 20 to 50 mesh range, were probably present or produced during transport to the the other laboratories. ANL reported wet sieving the samples to eliminate rock dust prior to use for the adsorption experiments. No other laboratory reported pre-experimental cleanup of the rock samples. This uncertainty in particle size distribution may be another cause for Kd variations.

Three main methods were used to separate of solid and solution phases: 1) centrifugation to produce supernatant solution for direct counting;

2) centrifugation and filtration of supernatant before counting; and 3) centrifugation, direct counting of the activity adsorbed on the solid, and direct counting of the supernatant. These differences in separation techniques could affect resulting Kd values.

Variations in the final $\mathrm{pH}$ of the rock-groundwater systems ranged from $0.8 \mathrm{pH}$ units for experiment \#1 to $1.3 \mathrm{pH}$ units in experiment \#3 (shown in Table 4). 
TABLE 4. Effluent pH Values

\begin{tabular}{|c|c|c|c|c|c|}
\hline \multirow[b]{2}{*}{ Lab } & \multirow{2}{*}{$\begin{array}{c}\text { Isotope } \\
\text { Used }\end{array}$} & \multicolumn{4}{|c|}{ Experiment } \\
\hline & & 1 & 2 & 3 & 4 \\
\hline \multirow[t]{3}{*}{ ANL } & $(\mathrm{Pu})$ & 7.6 & 6.6 & 7.5 & 6.5 \\
\hline & $(P u, C s)$ & 7.9 & 6.5 & 7.8 & 6.7 \\
\hline & $(S r)$ & 8.0 & 6.5 & 8.1 & 6.7 \\
\hline \multirow[t]{3}{*}{ AECL } & $(S r)$ & 7.6 & 7.4 & 7.4 & 7.3 \\
\hline & $(C s)$ & 7.8 & 7.4 & 7.4 & 7.3 \\
\hline & $(\mathrm{Pu})$ & 7.5 & 7.5 & 7.5 & 7.3 \\
\hline \multirow[t]{2}{*}{ LASL } & $(\mathrm{Sr}, \mathrm{Cs})$ & 8.5 & 6.8 & 8.4 & 6.8 \\
\hline & $(\mathrm{Pu})$ & 8.1 & 6.6 & 8.0 & 6.7 \\
\hline \multirow[t]{3}{*}{ ORNL-I } & $(S r)$ & 8.3 & 7.2 & 8.4 & 7.2 \\
\hline & $(C s)$ & 8.2 & 7.2 & 8.3 & 7.2 \\
\hline & $(\mathrm{Pu})$ & 8.2 & 7.2 & 8.2 & 7.2 \\
\hline \multirow[t]{2}{*}{ PNL } & $(S r, C s)$ & 7.9 & 7.1 & 8.7 & 6.9 \\
\hline & $(\mathrm{Pu})$ & 7.9 & 7.2 & 8.6 & 7.2 \\
\hline \multicolumn{2}{|c|}{ Target $\mathrm{pH}^{*}$} & $8.0-8.4$ & $6.0-7.0$ & $7.7-8.2$ & $6.0-7.0$ \\
\hline
\end{tabular}

1 = Limestone with limestone groundwater

$2=$ Limestone with brine

$3=$ Basalt with basalt groundwater

$4=$ Basalt with brine

* $=\mathrm{pH}$ range at the start of an experiment

The observed Kd values for cesium, strontium and plutonium are given in Tables 5, 6 and 7, respectively. Absorption of cesium (Table 5) by limestone in the presence of synthetic limestone groundwater (experiment \#1) was surprisingly varied with Kd values ranging over nearly three orders of magnitude. The distribution of Kd appeared to be lognormal, which may indicate that the Kd is a logarithmic function of some variable not recorded in this study. From the reported data, changes in $\mathrm{pH}$ and tracer concentration do not appear to correlate with the Kd variation. 
TABLE 5. Kd Values for $\mathrm{Cs}(\mathrm{ml} / \mathrm{g} \pm \mathrm{s} . \mathrm{d}$.

\begin{tabular}{|c|c|c|c|c|}
\hline \multirow[b]{2}{*}{ Lab } & \multicolumn{4}{|c|}{ Experiment } \\
\hline & 1 & 2 & 3 & 4 \\
\hline ANL $(a)$ & $65 \pm 2$ & $.14 \pm .01$ & $401 \pm 21$ & $1.48 \pm .05$ \\
\hline$A E C L(e)$ & $1.3 \pm .4$ & $.2 \pm .4^{(f)}$ & $31 \pm 2$ & $1.4 \pm .4$ \\
\hline LASL (b) & $88 \pm 1$ & $-.12 \pm .12^{(f)}$ & $265 \pm 4$ & $.6 \pm .2$ \\
\hline $\operatorname{LBL}^{(e)}$ & $49 \pm 5$ & $.16 \pm .9$ & $296 \pm 10$ & $1.52 \pm .04$ \\
\hline $\operatorname{LLL}^{(a)}$ & $60 \pm 30$ & $.5 \pm .5^{(f)}$ & $290 \pm 70$ & $1.6 \pm .1$ \\
\hline ORNL-I $(e)$ & $227 \pm 14$ & $.6 \pm .3$ & $380 \pm 5$ & $2.2 \pm .2$ \\
\hline ORNL-II ${ }^{(c)}$ & $663 \pm 61$ & $.1 \pm .3^{(f)}$ & $453 \pm 12$ & $1.79 \pm .01$ \\
\hline PNL ${ }^{(d)}$ & $880 \pm 160$ & $3.3 \pm .1$ & $380 \pm 70$ & $4.6 \pm .3$ \\
\hline $\mathrm{RHO}^{(e)}$ & $6.8 \pm .6$ & $.04 \pm .03^{(f)}$ & $255 \pm 7$ & $.95 \pm .13$ \\
\hline
\end{tabular}

\footnotetext{
(a) effluent was filtered

(b) effluent centrifuged at 16,000 rpm for $1 \mathrm{hr}$, decanted and repeated 3 times

(c) time of solution-rock contact was $700 \mathrm{hr}$

(d) effluent centrifuged for $20 \mathrm{~min}$. at $7000 \mathrm{rpm}$

(e) effluent was obtained by centrifugation and the blank correction used

(f) not significantly different from zero
}

The $\mathrm{Kd}$ values for $\mathrm{Cs}$, or $\mathrm{Kd}(\mathrm{Cs})$, in the remaining experiments, (\#2, 3 and 4), appeared more normally distributed about the mean Kd values. Tracer concentrations and measured final $\mathrm{pH}$ values had no apparent influence on $\mathrm{Kd}(\mathrm{Cs})$ in any of the controlled sample experiments.

Strontium adsorption was generally found to increase with an increase in $\mathrm{pH}$. Observed Kds in the limestone- 1 imestone groundwater system (experiment \#1) were not normally distributed. Instead, the Kds were apparently distributed exponentially with four less than $3 \mathrm{ml} / \mathrm{g}$, two between 3 and $6 \mathrm{ml} / \mathrm{g}$ and the remaining three greater than $9 \mathrm{ml} / \mathrm{g}$. Experiment \#1 was the on ly system in which $\mathrm{Kd}(\mathrm{Sr})$ did not appear to increase with an increase in $\mathrm{pH}$. 
TABLE 6. Kd Values for $\mathrm{Sr}(\mathrm{m} 1 / \mathrm{g} \pm \mathrm{s.d.})$

\begin{tabular}{|c|c|c|c|c|c|}
\hline \multirow[b]{2}{*}{ Lab } & \multicolumn{5}{|c|}{ Experiment } \\
\hline & 1 & 2 & 3 & & 4 \\
\hline ANL $(a)$ & $5.4 \pm 0.3$ & $0.18 \pm 0.01$ & $68 \pm 17$ & .05 & \pm 0.005 \\
\hline AECL & $1.8 \pm 0.5$ & $4.2 \pm 1.6$ & $41 \pm 6$ & 2.9 & \pm 0.4 \\
\hline LASL $^{(b)}$ & $1.4 \pm 0.2$ & $0.1 \pm 0.2$ & $81 \pm 1$ & 0.2 & \pm 0.2 \\
\hline LBL & $2.4 \pm 0.1$ & $0.1 \pm 0.1$ & $55 \pm 2$ & 0.1 & \pm 0.1 \\
\hline $\operatorname{LLL}^{(a)}$ & $2.7 \pm 0.5$ & $0.9 \pm 0.4$ & $45 \pm 1$ & 0.0 & \\
\hline ORNL-I & $5.9 \pm 0.2$ & $1.0 \pm 0.1$ & $89 \pm 5$ & 0.7 & \pm 0.3 \\
\hline ORNL-II ${ }^{(c)}$ & $9.3 \pm 2.4$ & $0.9 \pm 0.1$ & $93 \pm 6$ & 0.4 & \pm 0.1 \\
\hline PNL & $14.9 \pm 4.6$ & $3.4 \pm 0.3$ & $92 \pm 3$ & 3.6 & \pm 0.8 \\
\hline RHO & $13.4 \pm 0.6$ & $8.0 \pm 1.2$ & $73 \pm 4$ & 0.23 & \pm 0.02 \\
\hline
\end{tabular}

(a) effluents were filtered

(b) effluent centrifuged for $1 \mathrm{hr}$ at $16,000 \mathrm{rpm}$, decanted and repeated 3 times

(c) time of solution-rock contact was $7,000 \mathrm{hr}$

Results for $K d(C s)$ and $K d(S r)$ varied much more in the limestonelimestone groundwater system than in any of the other experiments. In general, $\mathrm{Kd}(\mathrm{Cs})$ and $\mathrm{Kd}(\mathrm{Sr})$ varied only by a factor of two in the basalt-basalt groundwater system. In the presence of the WIPP Brine, both $\mathrm{Kd}(\mathrm{Cs})$ and $\mathrm{Kd}(\mathrm{Sr})$ were reduced to low values. Tracer concentratons for $\mathrm{Sr}$ and $\mathrm{Cs}$ were not found to affect observed Kds in the controlled sample program.

Consistently high Sr and Cs Kds were observed by PNL. The only difference in procedure reported by PNL was the 20:1 solution to solid ratio used instead of $15: 1$ as reported by all other laboratories. The temperature at PNL $\left(27 \pm 2{ }^{\circ} \mathrm{C}\right.$ ) may have been higher than at the other laboratories, but no other temperatures were reported. The Kd values obtained at PNL, however, are consistent with other CS and Sr adsorption data obtained under the WISAP program at $\mathrm{PNL}^{(2)}$. 
Effects of solid to solution ratios on strontium Kds are discussed by Routson and Serne. ${ }^{(3)}$ Limited amounts of $\mathrm{Ca}^{2+}$ were available for dissolution in the soils used in their work. Increasing the solution to solid ratio resulted in a more dilute solution with a lower $\mathrm{Ca}^{2+}$ concentration, which increased $\mathrm{Kd}(\mathrm{Sr})$. It is not likely that $\mathrm{Ca}^{2+}$ availability was limited in the 1 imestone, however.

Co-precipitation or occlusion of nuclides ( $C S$ and $\mathrm{Sr}$ ) with monolayers of $\mathrm{CaCO}_{3}$, which may have formed on crushed limestone surfaces might account for some of the variability in $\mathrm{Kd}(\mathrm{Cs})$ for the controlled sample program. As temperature was not controlled, the solutions may have been near saturation with respect to $\mathrm{CaCO}_{3}$ and slight changes in the temperature could have caused a monolayer of precipitate to form or dissolve, scavenging or releasing nuclides. This process could lead to large variability in Kd determinations and could explain the larger than expected variations.

Very little adsorption by container walls was found for Cs and $\mathrm{Sr}$ as expected. Filtering CS and Sr effluent by ANL and LLL and supercentrifuging by LASL in conjunction with direct determination of adsorbed activity did not increase the observed Kds compared to the more slowly centrifuged, unfiltered, blank corrected Kd values observed.

Controlled sample adsorption Kds for plutonium are given in Table 7. Line plots of the reported Kds are shown in Figure 1. Filtered effluent blank corrected Kd values are generally larger than the corresponding values obtained with unfiltered effluent. Kds determined by direct measurement of absorbed activity were either larger than or no different statistically from the blank corrected $\mathrm{Kd}$ value obtained by the same experimental group doing both determinations. Direct measurements did not solve all problems, since at least one of the three Kd determinations by direct measurement of adsorbed activity was always an order of magnitude different from the other two values found. Reported plutonium tracer concentration and solution pH had no apparent affect on observed Kds, but the high variability in Kd might have masked this or any other functional dependency. 
TABLE 7. Kd Values for $\mathrm{Pu}(\mathrm{m} 1 / \mathrm{g} \pm$ s.d.)

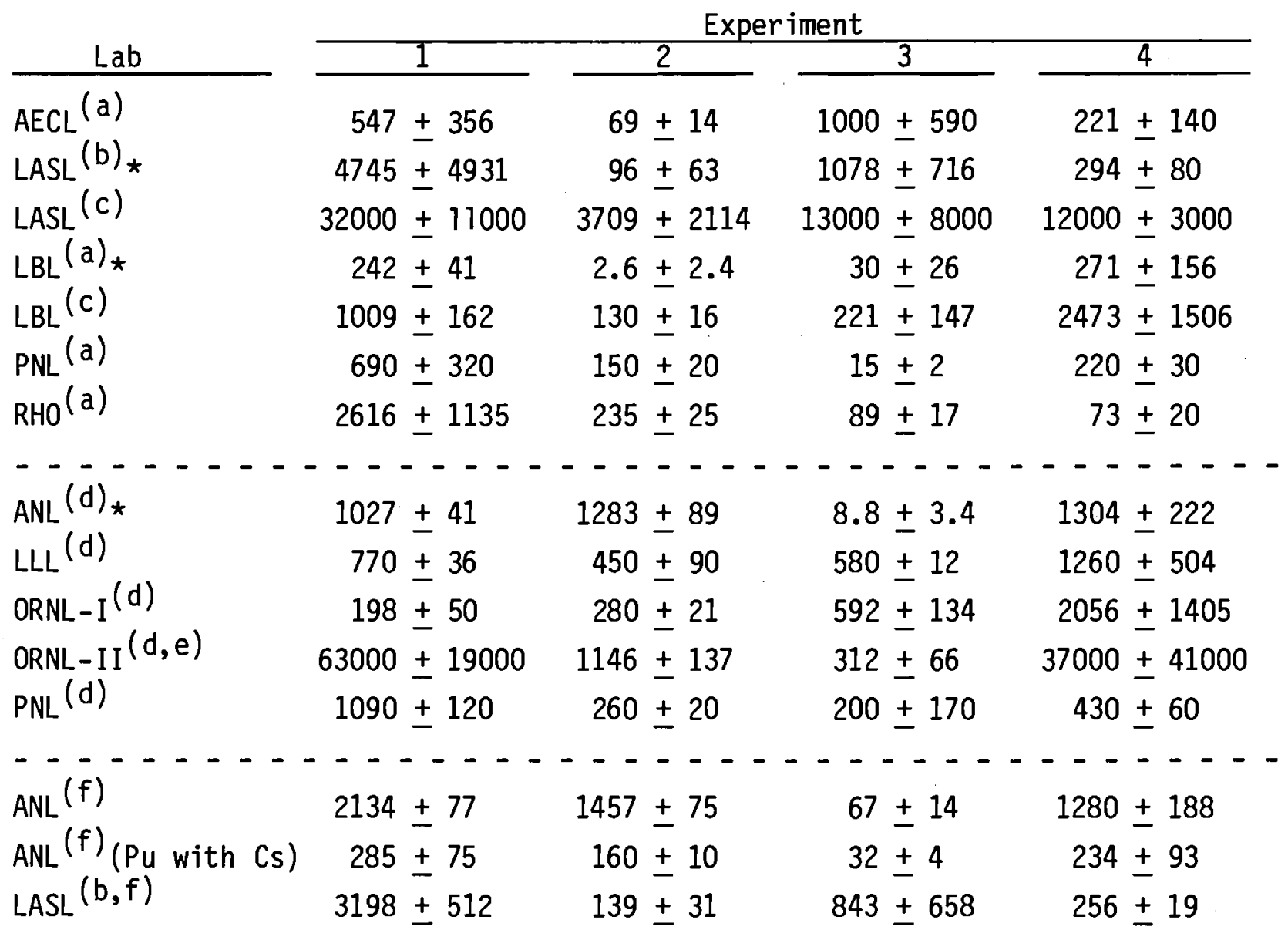

\footnotetext{
* some values recalculated by PNL using data supplied by subcontractors

(a) unfiltered effluent, Kd calculated with blank correction

(b) unfiltered effluent centrifuged at 16,000 rpm for $1 \mathrm{hr}$, decanted, repeated 3 times blank corrected

(c) unfiltered effluent, Kd calculated with original influent

(d) filtered effluent, Kd calculated with blank correction

(e) contact time $700 \mathrm{hr}$

(f) activity sorbed by rock measured directly
} 
$\nabla$ UNFILTERED EFFLLENT - BLANK CORRECTED

$\diamond$ FILTERED EFFLUENT - BLANK CORRECTED

$\triangle$ DIRECT MEASUREMENT OF ACTIVITY ADSORBED BY ROCK

ERROR BARS ARE ONE STANDARD DEVIATION

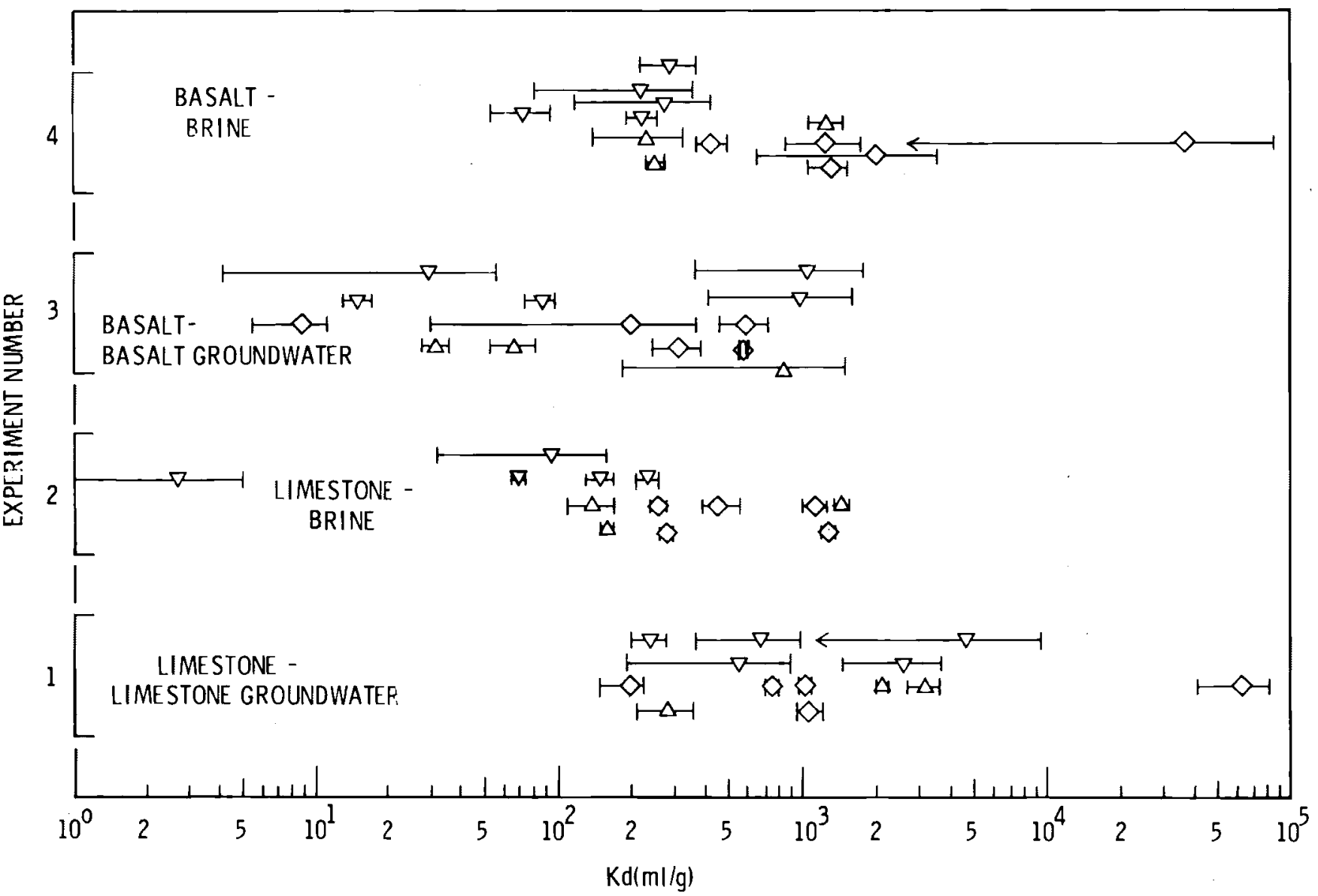

FIGURE 1. Measured $\mathrm{Kd}(\mathrm{Pu})$ Values Observed in the Controlled Sample Program. 
Two problems are readily apparent: 1) adsorption of $\mathrm{Pu}$ on colloidal particles (or formation of Pu colloids) in solution and 2) adsorption of Pu by container walls. Small particles may be essentially eliminated from the effluent by filtration, but Pu adsorption on the filter may then become a problem. Several labs reported that a sizable fraction of the $\mathrm{Pu}$ in the influent solution (up to $95 \%$ ) was removed by filtration before it came into contact with rocks. Adsorption of up to $90 \%$ of the added Pu by container walls was also reported for prefiltered influent solutions. Greater adsorption of Pu by container walls was reported by ANL and LBL in blank containers than in containers with crushed rock material. The ANL data from experiments 1 and 3 show th is effect. Adsorption of Pu by container walls in a blank corrected experiment lowers the apparent influent tracer concentration, giving a lower Kd than that obtained by direct measurement of the activity adsorbed on the solid and in the effluent. There was no difference (at a 95\% confidence level) detected at ANL between blank corrected and directly measured $\mathrm{Kds}$ for $\mathrm{Pu}$ in either of the brine experiments. No significant differences were observed at LASL between direct measurement of the Kd and blank corrected Kd for the same system. (The blank corrected value shown for LASL was calculated at PNL using additional data supplied by Dr. Bruce Erdal.)

There were insufficient data to determine whether or not the method with which a tracer was added to synthetic groundwater solutions had any affect on the resulting Kds.

\section{GONCLUSIONS}

The controlled sample program to date has identified differences of two to three orders-of-magnitude in certain experimental Kd values. It was anticipated that close agreement could be found for $\mathrm{Cs}_{s}$ and $\mathrm{Sr}$ adsorption results and that $\mathrm{Pu}$ would possibly behave erratically.

There was some agreement of $\mathrm{Kd}(\mathrm{Cs})$ and $\mathrm{Kd}(\mathrm{Sr})$ on both rocks in the brine. Adsorption results for both $\mathrm{Cs}$ and $\mathrm{Sr}$ in the dilute basalt and limestone groundwaters were more widely scattered than anticipated. $\mathrm{Kd}(\mathrm{Sr})$ values generally appeared to depend on the final solution $\mathrm{pH}$ but not on the tracer 
concentration. $K d(C s)$ values did not appear to be dependent on either final $\mathrm{pH}$ or tracer concentration. The reported data are insufficient to determine why $\mathrm{Kd}(\mathrm{CS})$ had a range of three orders of magnitude in the limestone-limestone groundwater system.

Batch adsorption determinations of $\mathrm{Kd}(\mathrm{Pu})$ were not satisfactory because of adsorption of Pu on container walls, formation of, or adsorption on, filterable particles, as well as other variables (e.g., pH, Pu concentration, spiking method) whose effects were masked by adsorption effects. Direct determination of $\mathrm{Pu}$ adsorbed by the rock and $\mathrm{Pu}$ in effluent solution also failed to reduce the variability in $\mathrm{Kd}(\mathrm{Pu})$ in a prescribed rock-solution system.

The controlled sample program points out the need for a more in-depth study of the factors controlling sorption-desorption reactions of radionuclides in geologic media. The distribution of a radionuclide between solid and solution phase has little meaning without detailed information that characterizes the radionuclide, the solution, and the geologic media of the system investigated. More specifically, information concerning the radionuclide chemistry in groundwater type solutions, mineral and precipitate formation and dissolution, adsorption and desorption mechanisms, and the equilibrium between groundwaters and geologic media is needed to predict concentrations of radionuclides in solution that are involved in transport processes.

Continuing studies, to explain and hopefully remove the larger than expected Kd variability, will be formulated. At present, safety assessments should consider the fact that confidence intervals for Kd values reported for rocks may be as large as two or three orders of magnitude for selected nuc lide-groundwater-rock systems. 


\section{$\underline{\text { REFERENCES }}$}

1. Ames, L. L., Controlled Sample Program Pulication No. 1, Characterization of Rock Samples, PNL-2797, 1978.

2. Relyea, J. F., L. L. Ames, R. J. Serne, R. W. Fulton and C. D. Washburne, Batch Kd Experiments with Common Minerals and Representative Groundwaters; in, Waste Isolation Safety Assessment Program, Task 4 Contractor Information Meeting Proceedings, PNL-SA-7352, 1979.

3. Routson, R. C. and R. J. Serne, Experimental Studies for the Percol and Transport Mode1s, BNWL-1719, 1972.

\section{LIST OF CONTRIBUTORS}

AECL T. T. Vandergraaf

ANL P. Rickert, M. G. Seitz, S. Fried, A. M. Friedman and M. Steindler

LASL B. R. Erda1, P. Q. Oliver, R. D. Aquilar and Francine Lawrence

LBL R. J. Silva and Larry Benson

LLL D. G. Coles, J. Tewhey, and D. Isherwood

ORNL-I Phyllis Rafferty and R. E. Meyer

ORNL-II C. W. Franc is and E. A. Bondietti

$\underline{\mathrm{RHO}}$ G. S. Barney

PNL R. W. Fulton, C. D. Washburne and J. F. Relyea 
APPENDIX A

\section{CONTROLLED SAMPLE PROGRAM}

\section{PURPOSE:}

Large quantities of rocks were obtained to provide all WISAP subcontractors with selected common samples. Through the use of common samples it should be possible to compare $\mathrm{Kd}$, sorption-desorption data or nuclide migration potentials among the various labs and among different experimental techniques. The main objectives are: 1) to ascertain whether different experimenters obtain comparable results using common rocks, standard solutions and a specified experimental design and 2) to ascertain the comparability of results obtained by individual laboratories using different experimental methodologies. In Objective 2 studies, we will investigate Kd value or nuclide migration dependencies on experimental methodologies, intending to formulate a standard $\mathrm{Kd}$ method or to derive calibration numbers to convert $\mathrm{Kd}$ numbers from one method to $\mathrm{kd}$ values from another method.

Ancillary objectives include generation of a Kd data bank on common rockgroundwater systems.

Rock materials acquired were crushed in a jaw crusher, and the 20 to 50 mesh size $(840$ to $297 \mu \mathrm{m})$ was selected. The dry sieved material was well mixed manually, and 1 gallon containers were filled. We realize that during crushing metallic impurities may have been added and that the resultant crushed rock may have acquired some artificial sorption qualities compared to the virgin rock. Neither of these potential problems will affect the main objectives of the controlled sample program.

Each laboratory recieved approximately 1 gallon each of the crushed rocks. In addition those who request can obtain large chunks (5-25 1bs) of the rocks to fabricate intact cores. 
The rock samples were characterized by PNL as follows:

- Bulk Chemical Analysis

- Mineralogy by X-ray Diffraction and Microprobe

- Cation Exchange Capacity

- Surface Area: Ethylene Glycol

\section{BET}

Results were supplied to all participants.

\section{OBJECTIVE 1: INTERLABORATORY COMPARISON}

A11 laboratories were directed to perform the following batch Kd exper iments:

EXP \#1

Geologic Material: Limestone

Groundwater:

\begin{tabular}{|c|c|c|c|}
\hline \multicolumn{2}{|c|}{$\mathrm{mg} / 1$} & \multicolumn{2}{|c|}{ PNL Recipe } \\
\hline $\mathrm{Ca}^{+2}$ & 50. & $\mathrm{Ca}(\mathrm{OH})_{2}$ & 92.5 \\
\hline $\mathrm{Mg}+2$ & 3.6 & $\mathrm{MgSO}_{4}$ & 18 \\
\hline $\mathrm{Na}^{+}$ & 2.3 & $\mathrm{NaCl}$ & 5.8 \\
\hline $\mathrm{K}^{+}$ & .4 & $\mathrm{KCl}$ & . \\
\hline
\end{tabular}

$\mathrm{HCO}_{3}^{-} \quad 153$ SPARGE with $\mathrm{CO}_{2}$ gas until

$\mathrm{SO}^{-2}$ all 1 ime dissolves and $\mathrm{pH}$

14.4 is $8.2-8.3$. If $\mathrm{pH}$ is below

pH $8.2 \pm .2 \quad \mathrm{Cl}^{-} \quad 3.5$ dissolved sparge with $\mathrm{N}_{2}$ Eh: Atmospheric $0_{2}$ equilibrated $\quad$ Aas to get back to $\mathrm{pH} 8.2$ overnight so excess $\mathrm{CO}_{2}$ and $\mathrm{N}_{2}$ can diffuse out.

Solid/solution: $1 \mathrm{~g} / 15 \mathrm{mls}$

Nuclides: $\mathrm{Sr}$ Measure $\mathrm{HCO}_{3}$ alkalinity and report.

Cs

Pu 237Pu will be made available to all

concentrations $<10^{-6} \mathrm{M}$ (must be measured)

Replicates: minimum of 3 replicates 
Geo logic Material: Limestone

Groundwater: WIPP Brine \#B (slightly altered)

\begin{tabular}{|c|c|c|c|}
\hline \multirow[b]{2}{*}{$\mathrm{Na}^{+}$} & \multirow{2}{*}{$\frac{\mathrm{mg} / 1}{115,000}$} & \multicolumn{2}{|c|}{ PNL Recipe } \\
\hline & & $\mathrm{NaCl}$ & 287. $\mathrm{g} / 1$ \\
\hline $\mathrm{K}^{+}$ & 15 & $\mathrm{Na}_{2} \mathrm{SO}_{4}$ & $6.2 \mathrm{~g} / 1$ \\
\hline $\mathrm{Mg}+2$ & 10 & $\mathrm{Na}_{2} \mathrm{~B}_{4} \mathrm{O}_{7} \cdot 10 \quad \mathrm{H}_{2} \mathrm{O}$ & $16 \mathrm{mg} / 1$ \\
\hline $\mathrm{Ca}^{+2}$ & 900 & $\mathrm{NaHCO}_{3}$ & $14 \mathrm{mg} / 1$ \\
\hline $\mathrm{Sr}^{+2}$ & 1.5 & $\mathrm{NaBr}$ & $520 \mathrm{mg} / 1$ \\
\hline $\mathrm{Cs}^{+}$ & 1 & $\mathrm{KCl}$ & $29 \mathrm{mg} / 1$ \\
\hline $\mathrm{Cl}^{-}$ & 175,000 & $\mathrm{MgCl}_{2}$ & $40 \mathrm{mg} / 1$ \\
\hline $\mathrm{SO}_{4}^{-2}$ & 3,500 & $\mathrm{CaCl}_{2} \cdot 2 \mathrm{H}_{2} \mathrm{O}$ & $3.3 \mathrm{~g} / 1$ \\
\hline $\mathrm{BO}^{-3}$ & 10 & $\mathrm{SrCl}_{2} \cdot 2 \mathrm{H}_{2} \mathrm{O}$ & $3.3 \mathrm{mg} / 1$ \\
\hline $\mathrm{HCO}_{\overline{3}}$ & 10 & $\mathrm{CsCl}$ & $1.3 \mathrm{mg} / 1$ \\
\hline $\mathrm{Br}^{-}$ & 400 & & \\
\hline
\end{tabular}

$\mathrm{pH}: \quad 6.5 \pm .5$

Eh: Atmospheric $0_{2}$ equilibrated (same as EXP \#1)

Solid/solution: $1 \mathrm{~g} / 15 \mathrm{mls}$

Nuc lides: $\quad s r$

Cs

$\mathrm{Pu}$

(same as EXP \#1)

Replicates: minimum of 3 (same as EXP \#1) 
EXP \#3

Geologic Material: Basalt

Groundwater:

\begin{tabular}{lc} 
& $\mathrm{mg} / 1$ \\
\cline { 2 - 2 } $\mathrm{Na}^{+}$ & 30 \\
$\mathrm{~K}^{+}$ & 9 \\
$\mathrm{Ca}^{+2}$ & 6.5 \\
$\mathrm{Mg}^{+2}$ & 1.0 \\
$\mathrm{HCO}^{-}$ & 58 \\
$\mathrm{SO}_{4}^{-2}$ & 23 \\
$\mathrm{Cl}^{-}$ & 16 \\
$\mathrm{~F}^{-}$ & 0.7
\end{tabular}

PNL Recipe

$\mathrm{NaHCO}_{3} \quad .95 \mathrm{meq} / 1 \quad 79.8 \mathrm{mg} / 1$

$\mathrm{Na}_{2} \mathrm{SO}_{4} \quad .35 \mathrm{meq} / 1 \quad 24.85 \mathrm{mg} / 1$

$\mathrm{MgSO}_{4} \quad .08 \mathrm{meq} / 1 \quad 4.81 \mathrm{mg} / 1$

$\mathrm{CaSO}_{4} \quad .07 \mathrm{meq} / 1 \quad 4.76 \mathrm{mg} / 1$

$\mathrm{CaCl}_{2} \quad .26 \mathrm{meq} / 1 \quad 14.42 \mathrm{mg} / 1$

KCl $\quad .20 \mathrm{meq} / 1 \quad 14.91 \mathrm{mg} / 1$

KF $\quad .04 \mathrm{meq} / 1 \quad 2.32 \mathrm{mg} / 1$

$\mathrm{pH}: \quad 7.7-8.2$

Eh: Same as EXP \#1

Solid/solution: Same as EXP \#1

Nuclides: Same as EXP \#1

Replicates: Same as Exp \#1

\section{EXP \#4}

Geologic Material: Basalt

Groundwater: Same as EXP \#2

pH: Same as EXP \#2

Eh: Same as EXP \#1

Solid/solution: Same as EXP \#1

Nuclides: Same as EXP \#1

Replicates: Same as EXP \#1 
Subcontractors are encouraged to use other controlled samples and pertinent nuclides also. WIPP Brine B represents one groundwater which could be used with all controlled samples. If you decide to perform batch Kd work on the other controlled samples, PNL will concoct an appropriate groundwater.

\section{PROCEDURE}

Make up aliquots of spike solutions (groundwater + nuclides), adjust $\mathrm{pH}$ to desired value. Equilibrate for at least 3 days. Check pH daily and adjust. Filter solutions through $0.45 \mu \mathrm{m}$ before contacting with "cold wash equilibrated" rocks.

Place material in container (suggest $1-2 \mathrm{~g}$ in $50 \mathrm{ml}$ Oak Ridge Polycarbonate Centrifuge tube). Wash material twice with cold solution (groundwater without spikes for periods of $\sim 48$ hours). Separate rock from cold solution by centrifugation. Discard cold washes.

Add known amount of spiked groundwater to rocks, contact for 7 days. Separate solution, count and calculate Kd. Blank containers (with no rocks) should be used to account for any container sorption. Nuclides may be mixed together or run separately.

PNL method of calculating Kd is shown in enclosure.

\section{OBJECTIVE TWO}

\section{METHODOLOGY EVALUATION}

Using the control rocks, groundwaters and nuclides specified, run your own style batch, flow through column, soil chromatography, axial filtration, etc., type of Kd experiments to compare with the results obtained for objective 1. You are also encouraged to use the other rock samples and pertinent nuclides in your program. As more large rock samples are obtained, other samples will be available. 


\section{BATCH Kd CALCULATIONS}

Tare weights are determined on $250 \mathrm{ml}$ polycarbonate screw cap centrifuge bottles. Well-mixed soils (5 to $10 \mathrm{~g})$ are weighed into the centrifuge bottles. Fifty mls of the simulated waste solution without the trace constituent are added to the centrifuge bottle. A piece of PARAFILM sealing material is placed over the mouth of the bottle before screwing down the cap to prevent solution leakage through the threads of the cap during the mixing stage. The capped bottle is placed in a variable speed shaker and moderately agitated for 30 minutes. The bottles are then centrifuged for 15-20 minutes at $4000 \mathrm{rpm}$ and the supernatant is carefully decanted. Loss of soil should be avoided. Three prewashes of the matrix solution (solution without the trace constituent) are performed. After the third decanting, the centrifuge bottle is reweighed and the amount of residual solution is calculated by difference. This value is needed because of the residual solution's dilution effect. Fifty mls of the simulated waste solution containing the trace constitutent are then pipeted into the centrifuge bottle and the capped bottle is agitated for a designated period. For tracer work in which pH is not important, shaking times of 18-24 hours are utilized. For $\mathrm{pH}$ dependent reactions, shaking times vary with the rate of change of solution $\mathrm{pH}$; solutions are centrifuged and extracted when the mixed solution attains the desired $\mathrm{pH}$. The sample is centrifuged, as before, and an effluent sample is extracted for analys is of the trace constituent.

Samples of the effluent and influent are then analyzed for the trace constituent. The Kd is calculated from equation:

where

$$
K d=\frac{r A i-A e}{A e} \frac{V}{W}
$$




$$
\begin{aligned}
& V=\text { total volume of solution in last treatment }(50 \mathrm{ml}+\mathrm{x} \text { residual } \\
& \mathrm{mls}) \\
& W=\text { total mass of soil present }(\mathrm{g}) \\
& \mathrm{r}=\text { ratio of tracer solution to total solution }(50 / 50+\mathrm{X}) \\
& \mathrm{Ai}=\text { activity of trace constituent in influent solution } \\
& \mathrm{Ae}=\text { activity of trace constituent in effluent solution }
\end{aligned}
$$





\section{DISTRIBUTION LIST}

No. of

Copies

OFFSITE

A. A. Churm

DOE Patent Division

9800 South Cass Avenue

Argonne, IL 60439

27 DOE Technical Information Center

2 Argonne National Laboratory Reference Library 9800 South Cass Avenue Argonne, IL 60439

Battelle Memorial Institute Office of Nuclear Waste I solation

Attn: Bever ly Rawles $505 \mathrm{King}$ Avenue

Columbus, $\mathrm{OH} 43201$

2 Brookhaven National Laboratory

Reference Section Information Division Upton, Long Island, NY 11973

20 Wayne A. Carbiener

Office of Nuclear Waste Isolation

Battelle Memorial Institute

505 King Avenue

Columbus, $\mathrm{OH} 43201$

Carl R. Cooley

DOE Office of Waste Management

Washington, DC 20545
No. of

Copies

\author{
Jared Davis \\ 27 Nuclear Regulatory \\ Commission \\ Washington, DC 20555 \\ Environmental Protection Agency \\ Office of Radiation Programs \\ Technical Assessment Division \\ AW559 \\ Washington, DC 20460 \\ Colin A. Heath \\ DOE Division of Waste Management \\ Washington, DC 20545 \\ William M. Hewitt \\ Office of Nuclear Waste \\ Isolation \\ Battelle Memorial Institute \\ $505 \mathrm{King}$ Avenue \\ Columbus, $\mathrm{OH} \quad 43201$ \\ Muzaffer Kehnemuyi \\ Office of Nuclear Waste \\ Isolation \\ Battelle Memorial Institute \\ $505 \mathrm{~K}$ ing Avenue \\ Columbus, $\mathrm{OH} 43201$ \\ John F. Kircher \\ Office of Nuclear Waste \\ Isolation \\ Battelle Memorial Institute \\ $505 \mathrm{~K}$ ing Avenue \\ Columbus, $\mathrm{OH} 43201$ \\ 2 Lawrence Berkeley Laboratory \\ Reference Library \\ University of California \\ Berkeley, CA 94720
}


No. of

Copies

2 Lawrence Livermore Laboratory

Reference Library

P.0. Box 808

Livermore, CA 94550

2 Los Alamos Scientific Laboratory

Reference Library

P.0. Box 1663

Los Alamos, NM 87544

John T. McGinnis

Office of Nuclear Waste Isolation

Battelle Memorial Institute

505 King Avenue

Columbus, $\mathrm{OH} \quad 43201$

2 Savannah River Laboratory

Reference Library

Aiken, SC 29801

Sheldon Meyers

DOE Office of Nuclear Waste

Management

Washington, DC 20545

2 Barry Naft

NUS Corporation

4 Research Place

Rockville, MD 20805

J. 0. Neff

Department of Energy

Columbus Program Office

505 King Avenue

Columbus, $\mathrm{OH} 43201$

2 Neil A. Norman

Environmental Sciences

Department

Bechtel National Inc.

P.0. Box 3965

San Francisco, CA 94105
No. of

Copies

2 Oak Ridge National Laboratory

Central Research Library

Document Reference Section

Oak Ridge, TN 37830

Howard P. Stephens

Sandia Laboratories

P.0. Box 5800

Albuquerque, NM 87115

David B. Stewart

U.S. Geological Survey

National Center 959

Reston, VA 22092

B. Allard

Transuranium Research Laboratory

Oak Ridge National Laboratory

P.0. Box $X$

Oak Ridge, TN 37830

Gary W. Beall

Oak Ridge National Laboratory

P.0. Box $X$

Oak Ridge, TN 37830

Larry Benson

Lawrence Berkeley Laboratory

1 Cyclotron Road

B 1dg 70A/1160

Berkeley, CA 94720

Ernest Bondietti

Oak Ridge National Laboratory

Bldg 3504

P.0. Box $X$

Oak Ridge, TN 37830

H. Clyde Clairborne

Oak Ridge National Laboratory

Bldg 3017

P.0. Box $X$

Oak Ridge, TN 37830 
No. of

Copies

Edward Norr is

Los Alamos Scientific Laboratory

P.0. Box 1663

Los Alamos, NM 87545

Paul Rickert

Argonne National Laboratory

9700 South Cass Avenue

Argonne, IL 60439

Barry E. Scheetz

Penn State University

Materials Research Laboratory

Room 223

University Park, PA 16802

Martin Seitz

Argonne National Laboratory

9700 S. Cass Avenue

Argonne, IL 60439

John Shade

University of Toledo

Toledo, $\mathrm{OH} 43606$

Victor Swan

Washington State University

Geology Department

Pullman, WA 99163

John Tewhey

Lawrence Berkeley Laboratory

$L-205$

P.0. Box 808

Livermore, CA 94550

Rosemary Vidale

Los Alamos Scientific Laboratory

P.0. Box 1663

Los Alamos, NM 87545

Barry G. Wahlig

School of Nuclear Engineering

Georgia Institute of Technology

Atlanta, GA 30332
No. of

Copies

Robert L. Watters

DOE Division of Biomedical and Environmental Research

Washington, DC 20545

Allen Weiss

Brookhaven National Laboratory

Bldg 830

Upton, L.I., NY 11973

\section{FORE IGN}

Bundesministerium fur Forschung und Technologie

Stressemannstrasse 2

D-5300 Bonn

F.R. of GERMANY

Ferruccio Gera

Radiation Protection and Waste Management Division

Nuclear Energy Agency/OECD

38 boulevard Suchet

75016 Paris

FRANCE

2 INIS Clearinghouse

International Atomic Energy Agency

P.0. Box 590

A-1011, Vienna

AUSTRIA

Library

Studsvik Energiteknik $A B$

S-611 01 Nykoping

SWEDEN

F. P. Sargent

Atomic Energy of Canada Limited

Whiteshell Nuclear Research

Establishment

Pinawa, Manitoba

Canada ROE 1LQ 
No. of

Copies

Jess M. Cleveland

Chief, Transuranium Research Project

USGS

Water Resources Division

Box 25046

Denver Federal Center

Lakewood, CO 80225

David G. Coles

Lawrence Livermore Laboratory

University of California

P.0. Box 808

Livermore, CA 94550

George A. Cowan

Los Alamos Scientific Laboratory

P.0. Box 1163

LosAlamos, NM 87545

Robert G. Dosch

Sandia Laboratories

P.0. Box 5800

Albuquerque, NM 87115

Geoffrey Eichholz

Regent's Professor of Nuclear Engineering

School of Nuclear Engineering

Georgia Institute of Technology

Atlanta, GA 30332

Bruce R. Erdal

Los Alamos Scientific Laboratory

CNC-11, MS-514

Los Alamos, NM 87545

Chet W. Francis

Oak Ridge National Laboratory

Bldg 2001

P.0. Box X

Oak Ridge, TN 37830

Sherman Fried

Argonne National Laboratory

9700 S. Cass Avenue

Argonne, IL 60439
No. of

Copies

Dana Isherwood

Lawrence Livermore Laboratory

MS L-224

P.0. Box 808

Livermore, CA 94550

George Al. Kolstad

DOE Division of Energy Research

Washington, DC 20545

Kurt Draus

110 Ogontz Lane

Oak Ridge, TN 37830

Harry Landon

NRC, Research Division

Washington, DC 20555

Paul W. Levy

Brookhaven National Laboratory

Physics Department

Upton, L.I., NY 11973

Stan E. Logan

Nuclear Waste Management Program

Los Alamos Technical Associates, Inc.

P.0. Box 410

Los Alamos, NM 87554

I. Wendell Marine

E. I. du Pont de Nemours Co.

Savannah river Laboratory

Aiken, SC 29081

Robert E. Meyer

Oak Ridge National Laboratory

P.0. Box X

0ak ridge, TN 37830

Anthony Mucciardi

Adaptronics, Inc.

Westgate Research Park

7700 01d Springhouse Road

Mclean, VA 22101 
No. of

Copies

Egbert Schapermeier

Battelle-Institute e.V.

Am Romerhof 35

D-6000 Frankfurt am Main 90

$F . R$. of GERMANY

Dr. Les Dole

c/o Dr. Klaus Kuhn

Institut fur Tiefiagerung

Wissenschaftiiche Abtei iung

Berliner Strasse 2

D-3392 Clausthal - Zellerfeld

West Germany (FRG)

Robert Gillham

Department of Earth Sciences

University of Water 100

Water 10o, Ontario

CANADA

David Grey

Institute of Geologic Sciences

Exhibition Road

S. Kensington

London, SW7-2DE

UNITED KINGDOM

Alex T. Jakubick

Nuclear Research Center

$7500 \mathrm{Kar}$ lsruhe

P.0. 3640

FEDERAL REPUBLIC OF GERMANY

Tjalle Vandergraff

Atomic Energy of Canada Limited

Whiteshel1 Nuclear Research

Establishment

Pinawa, Manitoba

CANADA ROE 1 LO
No. of

Copies

8 Rockwell Hanford Operations

R. C. Arnett

G. S. Barney

R. A. Deju

M. R. Fox

G. S. Hunt

M. J. Smith

W. W. Schulz

Rockwe 11 Document Control

60 Pacific Northwest Laboratory

L. L. Ames

G. L. Benson

A. Brandstetter (10)

D. B. Cear lock

D. J. Bradley

M. A. Harwel 1

B. W. Howes

M. R. Kreiter

A. M. Platt

D. Rai

J. R. Raymond

J. F. Relyea (5)

R. J. Serne

R. G. Strickert

R. P. Turcotte

Technical Information Library (5)

Publishing Coordination (2) Water and Land Resources RO

\section{ONSITE}

6 DOE Richland Operations Office

0. J. Elgert

R. B. Goranson

H. E. Ransom

J. J. Schreiber

D. J. Squires

F. R. Standerfer 
